UDK: $343.24(4)$

364-781.9:343.22(4)

\title{
OFFENDER SUPERVISION IN EUROPE - GENERAL TRENDS AND SERBIAN EXPERIENCE
}

\author{
Jelena Zeleskov Djoric * \\ Ana Batricevic ** \\ Institute of Criminological and Sociological Research, Belgrade
}

Summary: Offender supervision represents an important mechanism applied during the execution of criminal sanctions and measures, especially of community or alternative sanctions. Official reports of some European countries suggest that the application of offender supervision is starting to deliver satisfactory results in crime prevention and suppression. Serbian normative framework for offender supervision was set in 2006, when community service was introduced, and improved by amendments of 2009. Strategy on the Minimization of Over-population of Institutions for the Execution of Criminal Sanctions in the Republic of Serbia between 2010 and 2015, recommended alternative sanctions as the most efficient means to reduce the number of prisoners, especially by applying the "house prison", with or without electronic surveillance. Draft normative framework Serbian legislator is about to adopt comprises: Strategy of the development of the system of execution of criminal sentences between 2013 and 2020, Law on the Execution of Criminal Sanctions and Law on the Probation of Execution of Non-custodial Sanctions and Measures. These documents emphasize the contribution of offender supervision in the enforcement of probation during fulfilling: obligations in accordance with public prosecutor's decision to delay criminal prosecution, plea bargain agreement, ban to leave one's apartment with or without electronic surveillance, ban to approach, meet or communicate with a particular person, community service, conditional sentence, "house prison“, conditional release and post-

* Naučni saradnik, jelena.zeleskov.djoric@gmail.com

* Naučni saradnik, a.batricevic@yahoo.com 
penal treatment. Therefore, European legislative solutions and practical experiences are analyzed as possible role-models for future development of offender supervision and probation in Serbia.

Keywords: offender supervision, alternative sanctions, community service, electronic surveillance, probation.

\section{Introduction}

Thorough analysis of various theoretical approaches and definitions of alternative or community ${ }^{3}$ or intermediary sanctions ${ }^{4}$ suggests that this term comprises measures designated to avoid the application of institutional penalties, particularly imprisonment, in order to avoid negative effects of imprisonment, provided that they are imposed by judicial bodies and compliant with the nature of the criminal offence and personal characteristics of the offender ${ }^{5}$. Depending on actual solutions prescribed in national laws, alternative sanctions may include various activities such as: fulfillment of particular obligations, drug or alcohol abuse treatment, psychological advising and assistance, community service, compensation of damage for the victim etc. Some of the activities that comprise alternative sanctions may be accompanied by surveillance - whether electronic of conducted through regular meetings with the supervisor. The aim of alternative sanctions is either to avoid the conduct of criminal procedure and impose the punishment or to improve the re-socialization of offenders through the accomplishment of particular obligations and tasks and participation in social, pedagogical or medical treatment and partial imprisonment ${ }^{6}$. Until recently, our country has not experienced significant efforts in the field of application of sanctions and measures that are alternative to imprisonment ${ }^{7}$. In the past couple of years some steps have been made to improve current state in this area of penal law, but new legislative framework, regulating alternative sanctions and post-penal treatment, that is about to be adopted, should establish genuine preconditions for substantial positive changes. At the moment, these documents exist only in the form of drafts, the most important of which is Draft Law on Probation ${ }^{8}$.

Offender supervision is particularly important in the enforcement of probation which, according to Draft Law on probation includes: 1) supervision of the fulfillment of obligations in accordance with public prosecutor's decision to delay criminal prosecution, 2) supervision of the fulfillment of obligations derived from plea bargain agreement, 3) supervision of the execution of ban to leave one's apartment with or without electronic surveillance, 4) supervision of the

3 S. Konstantinović Vilić; M. Kostić, Penologija, Niš, 2006, str. 240.

4 Z. Nikolić, Savremena penologija, Beograd, 2009, str. 85.

5 M. Bošković; M. Radoman, Penologija, Novi Sad, 2002, str. 90.

6 N. Mrvić-Petrović; Đ. Đorđević, Moć i nemoć kazne, Beograd, 1998, str. 96-97.

7 N. Mrvić-Petrović, Alternativne sankcije i novo zakonodavstvo Republike Srbije, Temida, br.1/2006, Beograd, str. 55 .

8 Draft Version of the Law on Probation of Execution of Non-custodial Sanctions and Measures [online], available at: http://www.mpravde.gov.rs/files/ZAKON\%20O\%20PROBACIJI\%2013\%20 5-13.doc (15.12.2013) 
execution of ban to approach, meet or communicate with a particular person, 5) organization, enforcement and supervision of community service, 6) protective supervision in case of conditional sentence, 7) supervision of the execution of prison sentence in the premises where the convicted person lives, 8) supervision of conditionally released prisoners and 9) post - penal support and assistance. The Ministry of Justice and Public Administration, precisely special organizational unit for Treatment and Alternative Sanctions, within the Administration for the execution of criminal sentences is in charge for the enforcement of probation. The unit is functioning through the cooperation with relevant state bodies and civil sector representatives through a network of local probation officers.

\section{European Experience}

Due to the fact that our country still needs to undertake significant steps in order to develop a comprehensive legislative framework for the efficient imposing and implementation of alternative sanctions, solutions prescribed by European countries with a longer and richer tradition in this field should be taken into account as possible role models and valuable guidelines. Therefore, normative framework and some practical aspects of alternative sanctioning in England and Wales, Ireland, The Netherlands and Switzerland are analyzed, with special focus on conditions, modalities and entities in charge of conducting offender supervision. The countries discussed in this paper are chosen with regard to the fact that their representatives are participating in COST Action IS1106 dedicated to research of offender supervision in Europe and, therefore, were able to deliver relevant statistical data of high validity and reliability.

\subsection{England and Wales}

Probation in England and Wales has traditionally drawn upon social work values and practice ${ }^{9}$. The use of community sentences by the courts increased by 28 per cent between 1999 and 2009. A key driver behind this expansion has been the desire to use community sentences as a mechanism for controlling the prison population but the reality has been one of unprecedented penal expansionism in both the use of imprisonment and community sanctions. Nowadays, there are approximately 243,000 individuals under probation service supervision in England and Wales of which 141,000 were under a court order and 102,000 were under license following a period of imprisonment ${ }^{10}$.

9 L. Burke, W. Fitzgibbonn, Working Group on Experiencing Supervision Country Report: England and Wales. COST Action IS1106 Offender Supervision in Europe., 2013, str. 1. [online], available at: http://www.offendersupervision.eu/wp-content/uploads/2013/02/Experiencingsupervision-England-and-Wales-Country-Report-FINAL.pdf (15.12.2013).

10 Ministry of Justice, Offender Management Caseload Statistics 2009: An Overview of the main findings. Ministry of Justice Statistics Bulletin. United Kingdom: Ministry of Justice, 2010 [online], available at: https://www.gov.uk/government/uploads/system/uploads/attachment_ data/file/218064/omcs-chapter1-standalone.pdf (15.12.2013). 
The Criminal Justice Act, adopted in 2003, legislated for a new framework pertinent to the implementation of community sentences by replacing the previously existing system of alternative sanctions with a generic community order. Such solution enabled the judicial bodies that impose this type of sentences to 'mix and match' the sentence depending on the specificities of each individual case and choose one or more of 12 possible requirements, including: unpaid work and supervision, accredited program that has to be combined with a supervision requirement, drug rehabilitation, alcohol treatment, mental health treatment, residence, specified activity, prohibited activity, exclusion, curfew and attendance centre ${ }^{11}$.

The actual content and the form in which community sentences are applied, has also changed in England and Wales in the past couple of years. Namely, there has been a decline in the use of supervision and accredited programs (both measures aimed at facilitating the rehabilitation of offenders) within the orders. Whatever the intensity and potential intrusions of community sentences, which are often referred to as "the pains of probation" 12 have also developed considerably in recent decades, moving beyond traditionally rehabilitative supervision to include unpaid work, medical, psychological or substance misuse treatment, mandatory drug or alcohol testing, exclusion orders and residence conditions, curfews, as well as other innovations such as electronic monitoring.

Community sentences in England and Wales are currently administered by 35 Probation Trusts who are wholly funded by central government as part of the National Offender Management Service. These trusts are accountable to the Ministry of Justice for their performance and delivery ${ }^{13}$. Although the number of probation staff members grew by two thirds between 2000 and 2006, it has decreased since by a fifth ${ }^{14}$.

\subsection{Ireland}

Although there are authors who claim that common law countries are more prone to alternative sanctioning than countries of the Balkan region such as Serbia, for example ${ }^{15}$, most commentators agree that the Irish Probation Service has remained marginalized, under- resourced and neglected throughout much of its history ${ }^{16}$. The situation is similar in the present as well since it seems that probation supervision in Ireland continues to be governed by the Probation of Offenders Act 1907, which was enacted before Ireland gained independence from Britain ${ }^{17}$. The only significant criminal legislation reform conducted in the

\section{L. Burke, W. Fitzgibbonn, Opus citatum, str. 3.}

12 I. Durnescu, Pains of Probation: Effective Practice and Human Rights. International Journal of Offender Therapy and Comparative Criminology, br. 4/2010, London, str. 530.

13 L. Burke, W. Fitzgibbonn, Opus citatum, str. 4.

14 R. Garside, H. Mills, UK Justice Policy Review. Volume 1. London, 2012, str. 24.

15 Z. Nikolić, Opus citatum, str. 85.

16 M. Seymour, Alternatives to Custody in Ireland Report. Dublin, 2006 , str. 16., D. Healy, Probation matters, Irish Jurist, 44/2009, str. 239-257.

17 D. Healy, Experiencing Supervision in Ireland. COST Action IS1106 Offender Supervision in Europe, 2012 [online], available at: http://www.offendersupervision.eu/wp-content/ uploads/2012/08/Experiencing-Offender-Supervision-in-Ireland.pdf (15.12.2013.) 
past one hundred years was the adoption of Community Service Act 1983. This legal act empowers judges to impose a community service order of between 40 and 240 hours instead of custodial sentence ${ }^{18}$.

Ireland's rate of imprisonment currently stands at 100 per 100,000 population ${ }^{19}$ suggesting that the frequency of custodial sentences is relatively high in this jurisdiction. For example, there were 17,318 committals to prison in $2011^{20}$. However, examination of long-term sentencing trends reveals a gradual but steady rise in the number of supervision orders made between 1980 and 2011. In spite of these improvements, community sanctions still account for less than $10 \%$ of all sentences handed down by the courts ${ }^{21}$. The recent trend towards actuarial justice in community sanctions has been extensively criticized by criminologists $^{22}$, emphasizing that effective practice should build agency, human and social capital, focus on strengths as well as risk and need, foster relationships and operate within a framework that is both legitimate and rights-based ${ }^{23}$.

In addition, community service orders are mainly used in cases involving firsttime offenders and those who have committed minor offences - cases that may not otherwise have attracted a prison sentence ${ }^{24}$, but one fifth of young offenders had no contact with the Probation Service prior to serving their first custodial sentence ${ }^{25}$ Similarly to the conditions in Serbia, one of the reasons for that may be the fact that probation services lack professional staff members and capacities. Namely, apart from supervising the offenders on community service, probation officers also work with prisoners, including those serving suspended prison sentences in the community ${ }^{26}$ and those who are on temporary release from custody. Another reason is "a strong orientation towards custody among Irish judges", which is particularly highlighted in as study on judicial practice in Ireland conducted by O'Donnell in $2004^{27}$. Moreover, Seymour concluded that the outlook for community sanctions was "pessimistic" on the basis of limited legislative reform,

18 G. McNally, Probation in Ireland, Part 2: The modern age,' Irish Probation Journal, 1/2009, str. 187-228.

19 R. Walmsley, World Prison Population List (9th Ed). Essex, 2011, str. 5.

20 Irish Prison Service, Annual Report 2011. Dublin, 2012, str. 14, [online], available at: http:// www.justice.ie/en/JELR/Annual\%20Report\%20IPS\%202011.pdf/Files/Annual\%20Report\%20 IPS\%202011.pdf, (15.12.2013).

21 Irish Court Service. (2012). Annual Report 2011. Dublin, 2012, str. 21-52. [online], available at: http:// www.courts.ie/Courts.ie/library3.nsf/(WebFiles)/87BE463114EF96FF80257BA20033953B/\$FILE/ Courts\%20Service\%20Annual\%20Report\%202012.pdf (15. 12. 2013.)

22 H. Kemshall, Risk, rights and justice: Understanding and responding to youth risk, Youth Justice, br. 2008/1, London, str. 21-37.

23 F. McNeill, A desistance paradigm for offender management, Criminologyand Criminal Justice, 1/2006, London, str. 39-62.

24 D. Walsh, P. Sexton, An Empirical Study of Community Service Orders in Ireland. Dublin, 1999, in: D. Healy, Opus citatem, str. 2-3.

25 V. Geiran, M. McCarthy, M. Morahan, V. O'Connell, Young Offenders in Penal Custody. Research and Statistics Unit, Probation and Welfare Service, Dublin, 1999, in: D. Healy, Opus citatem, str. 6.

26 Criminal Justice Act, Irish Statute Book, Number 26 of 2006 [online], available at: http:// www.irishstatutebook.ie/2006/en/act/pub/0026/ (16. 1. 2014).

27 I. O'Donnell, Imprisonment and penal policy in Ireland, The Howard Journal of Criminal Justice, 3/2004, str. 253-266. 
chronic under-resourcing, lack of sentencing guidelines, and a dearth of research ${ }^{28}$. The prospects for community sanctions have since become more promising and there appears to be a belated recognition among politicians that the high costs of imprisonment are unsustainable, particularly during a period of economic difficulty. Finally, it is worth mentioning that the national recidivism rate for people under probation supervision in Ireland has never been calculated, so it is hard to estimate their efficiency, but it is known that around $80 \%$ of community service orders are completed successfully, which indicates a high level of compliance ${ }^{29}$.

\subsection{The Netherlands}

The Netherlands probation system, which is also implemented in Serbia as a role model, could be a valuable example how Probation Service and State could collaborate together on this issue. The Dutch probation system consists of three organizations: Probation Service Netherlands, which is the biggest private probation organization with 1500 full time employees, followed by the Probation Service for addicted offenders, where nearly 450 persons work, and Salvation Army Probation Service with 220 full time employees. All these organizations are funded by the State and cooperate between themselves ${ }^{30}$

The Ministry of Justice plays the essential role in this mechanism, due to the fact that political responsibility for the (non-state) probation organizations is under its jurisdiction. The structure of these probation organizations is defined through a network of regional offices. In each of 19 districts that the Netherlands is divided into, Public Prosecutors agencies for registration, selection and allocation are used as the probation counters locations. The main goal of these offices is to maintain contact with various partners in the judicial chain (Public Prosecuting Office, Custodial institutions, Police) and with the municipalities to deliver service geared to the type of problems as defined. It is notable that Probation Services provides services to adults only, whereas for minor offenders separate organizations are formed. Nevertheless, Salvation Army also works with homeless and juveniles persons who are in multi-problem situations ${ }^{31}$

Also, criminal justice process and Probation Service tasks are intertwined, which means that the Service participates in each stage of the criminal justice process, from arrest to enforcement. Moreover, the Probation Service is involved in the execution of the following activities: diagnosis and advice, supervision of conditional sanction modalities; performing behavioral interventions, performing task penalties, in particular labor penalties. However, it is important to be aware of the fact that The Probation Service can only perform probation activities as commissioned by the

$28 \quad$ M. Seymour, Opus citatum, str. 10.

29 Petrus, Value for Money and Policy Review of the Community Service Scheme, Dublin, 2009, [online], available at: http://www.justice.ie/en/JELR/FINAL\%20CSO\%20VFM\%20-\%20 October\%2009.pdf/Files/FINAL\%20CSO\%20VFM\%20-\%20October\%2009.pdf, (16. 1. 2014).

30 V. Hoetjes, J. Plaisier, Experience of Probationers with the Dutch Probation Services: a quick scan. COST Action IS1106 Offender Supervision in Europe, 2012, str. 3. [on line], available at: http://www.offendersupervision.eu/wp-content/uploads/2012/08/Offender-supervision-in-TheNetherlands.pdf (16. 1. 2014).

31 Ibidem, str. 4.

[80] NBP • Žurnal za kriminalistiku i pravo 
judicial authorities: the Public Prosecutor Service, the judiciary and the prison system. Hence, no 'voluntary contact' with detainees is possible. Ex-detainees are supervised by the Probation Service in case of congruency with the framework of the Penitentiary Program or for the conditional release if special conditions have been imposed. In 2008 the new law on conditional release with supervision by probation service came into force, followed by the project, the goal of which was to improve transition from penitentiary institutions to community, and implement modern trends in advising and supervision, with regard to the fact that $70 \%$ of the detainees are sentenced again within six years. Furthermore, the Netherlands probation system recognized the importance of connectedness with the world of science and, therefore supports the research programs, improvement in education and training, special 'probation' professors and lecturers employed in universities and schools of social work ${ }^{32}$.

At the end, we should not forget that the criminal procedure is comprised of different stages. Application of probation in the Netherlands could be seen in numerous stages of criminal procedure, including pre/trial phase, trial and enforcement phase and post release phase. Some of the probation activities are implemented in all three phases, such as supervising special measures for drug addicts and preparing a social enquiry or recommendation request. Others, such as supervising community service, supervising drug or alcohol treatment programs and pre/sentence report are applied in the pre/trial and trial phase ${ }^{33}$. To summarize, the Dutch probation system could be a very good example of structured, wellorganized and applicable role model for our country. Some steps have already been made in that direction in 2008, when Serbian Administration for the enforcement of criminal sanctions participated in the project funded by the Embassy of the Kingdom of the Netherlands and supported by the OSCE Mission in Serbia. A working group composed of 5 local experts was set up with the task to determine key strategic aims, mission and vision of the Commissioners' Service.

The working group created a paper "The Role of Commissioners' Service in the System of Enforcement of Penal Sanctions". The document defines the mission, basic principles and values, strategic aims and tasks of the Commissioners' Service as well as vision of its further development and is fully compliant with strategic aims defined in the Strategy for Implementation of Alternative Sanctions, Law on Enforcement of Penal Sanctions and missions of probationary services of other countries. By the Decision of the Administration Director, this document was adopted as a directive stipulating mode of work, procedures and conducts of commissioners in charge of enforcement of the sanctions of community service and suspended sentence with protective supervision and distributed to judges and prosecutors. Also, in August 2008 the OSCE Mission to Serbia signed an agreement with the Probation Service of the Kingdom of the Netherlands stipulating engagement of experts of the Dutch probation service in the education of Serbian probation officers and prison staff ${ }^{34}$.

32 A. M Kalmthout, I. Durnescu (Eds.), Probation in Europe, Nijmegen, The Netherlands 2009, str. 677-724.

33 Ibidem.

34 D. Joka, The 2008 Annual Report on Prison Administration work. Belgrade, 2009, str. 80. 


\subsection{Switzerland}

Until 2011, when the national Criminal Procedure Code ${ }^{35}$ was adopted, all 26 cantons in Switzerland had their own criminal procedure codes. According to Article 237 of the Code court may order one or more alternative measures instead of remand, if alternative measures achieve the same purpose as remand. Alternative measures may include the following: requirement to stay or not to stay in a specific place or in a specific house, to report to a public office at regularly intervals, to do a regular job or to undergo medical treatment or a medical examination together with the prohibition to make contact with specific persons. The fulfillment of these obligations may be supervised with the support of electronic devices. When deciding whether to impose an alternative sanction or not, the court is not bound by the request of the public prosecutor or the offender, particularly if the demand refers to the extension of the period on remand or if the accused applies for unconditional release. The alternative measures may be revoked at any time or replaced with other alternative measures.

Community service, as a special alternative sanction, was introduced to Swiss legal system in 2007, after amendments and alterations of relevant legislative framework. So, after the alterations, the following alternative sanctions specified in the Articles 34 to 41 of the Swiss Criminal Code ${ }^{36}$ may be imposed: fine, custodial sentence or community service. Community service may be imposed instead of custodial sentence of less than 6 months or a fine not exceeding 180 daily penalty units. In the context of this sentence, community service and fine take precedence over custodial sentences that can be ordered only if special prerequisites are met.

Furthermore, during the probationary period, specific conduct orders that refer to a profession, place of residence, medical and psychological therapy may be imposed on the offender. Conduct orders may also be imposed by the court as additional measures in the case of an out-patient measure, as post-penal obligation or if a custodial sentence is suspended. Moreover, these sanctions may also be ordered by the public prosecutor in summary penalty order procedure. The sentences may be combined with probation assistance and conduct orders. The supervision of conduct orders falls under the jurisdiction of cantonal execution authorities and probation officers.

Provided that specific requirements are fulfilled, short custodial sentences of no more than 12 months can be executed in the form of electronically supervised home detention in seven cantons (Bern, Basel-City, Basel-Country, Solothurn, Geneva, Vaud, Ticino), but only upon the request of the offender and the order of the execution authority. In these cantons electronically monitored home detention can also be applied during external accommodation of offenders who are serving long custodial sentences. In such cases, the offender is obliged to serve at least half of his custodial sentence in a penal institution. Electronic monitoring cannot last longer than 12 months $^{37}$

35 Swiss Code of Criminal Procedure of October 5, 2007 (status as of January 1, 2011), [online], available at: http://www.wipo.int/wipolex/en/details.jsp?id=9242 (16.1.2014).

36 Ibidem.

37 J. Weber, J. Nett, Country Report for Switzerland - A contribution to the working group no. 1

[82] NBP • Žurnal za kriminalistiku i pravo 
Since 1996, there was a shift from custodial sentences that were executed by semi-detention to the execution in the form of community service. Between 2002 and 2006 the number of individuals engaged in community service increased as well as the number of those serving their time in normal detention. Since the latest revision of the Swiss Criminal Code in 2007, the importance of other sanctions has considerably increased and they have partly ruled out unsuspended custodial sentences as main sanctions. However, after the introduction of community service, as an alternative to a custodial sentence (and not only as an alternative form of execution of custodial sentences), the number of cases with community service decreased substantially ${ }^{38}$.

If the prison inmate has served two thirds of his sentence, he can be released on parole with a probationary period of 1 to 5 years. The execution authority may additionally impose probation assistance and conduct orders during the probationary period, particularly practice of a profession, the place of residence, medical and psychological therapy.

According to Weber \& Nett in 2011 the human resources of the probation services in Switzerland consisted of 192 appointments with the offenders (in full time equivalents), of which 124 related to personnel with education in social work. The supervision rate of social worker, i.e. the number of assignments and additional tasks per client, was 51; including community services and electronic monitoring the rate amounts to $64 .{ }^{39}$

\section{Serbia - Current State, Efforts and Plans for Future Actions}

As mentioned previously, supervision of adult offenders, either in the form of regular contacts with probation officers or in the form of electronic surveillance seems to be one of the key elements of the enforcement of alternative noncustodial sanctions as well as of the post-penal treatment of former prisoners. The importance of this kind of offender supervision is double-layered. On one hand, it is aimed to contribute to a complete and successful re-socialization and social reintegration of offenders as well as to the reduction of recidivism, whereas on the other, it is expected to increase public safety, protect the needs and interests of the victims and minimize the risk of re-victimization.

Since the application of this type of offender supervision is directly linked to the enforcement of alternative sanctions, it can be said that necessary preconditions for its implementation in the penal system of the Republic of Serbia had not been met until January $1^{\text {st }} 2006$, when a set of new laws and sublegal documents, pertinent to substantial criminal law, criminal procedure, execution of criminal sanctions and juvenile delinquents, came into force. The following legal documents came into force on that occasion: Criminal Code of

\& 2: Experiencing Supervision and Decision-Making. COST Action IS1106 Offender Supervision in Europe, 2013, str. 13. [online], available at: http://www.offendersupervision.eu/wp-content/ uploads/2013/05/Offender-Supervision-in-Switzerland.pdf (16.1.2013).

38 Ibidem, str. 11.

39 Ibidem, str. 15. 
the Republic of Serbia ${ }^{40}$, Code of Criminal Procedure ${ }^{41}$, Law on Execution of Criminal Sanctions ${ }^{42}$ and Law on Juvenile Perpetrators of Criminal Offences and Criminal Legal Protection of Juveniles ${ }^{43}$. Moreover, some additional sub-legal documents i.e. more detailed and precise rules and regulations dedicated to some specific issues and institutions mentioned in these laws were also adopted.

Some forms of alternative sanctions for adult offenders existed in Serbian penal legislation even before this legislative reform. These comprised: judicial admonition, confiscation of driving license, fine and conditional sentence ${ }^{44}$. However, the first step towards the establishment of a contemporary system of community or alternative sanctions including offender supervision in our country was set in 2006, when punishment of community service was prescribed by Paragraph 52 of current Criminal Code. The adoption of Law on Execution of Criminal Sanctions was accompanied by the adoption of two sublegal acts, necessary for its practical implementation: Regulation on the Enforcement of Conditional Sentence with Protective Supervision ${ }^{45}$ and Regulation on the Enforcement of Community Service $^{46}$. These legal documents precisely prescribe the duties and obligations of officer in charge of supervision of convicted person. It is prescribed that the probation officer performs his duties within the Probation Service Office, which is about to become an independent service functioning under the auspices of Ministry of Justice and Public Administration. Three tasks of this service can be highlighted as the most important: to enforce the decisions of judiciary bodies, to improve public safety and to enhance social reintegration of former prisoners. The Officer is empowered to supervise the convicted person, establish and maintain regular contacts with him, to cooperate with relevant judiciary bodies, police officers, employers and other institutions, organizations and associations, as well as to require and obtain data contained in official records and other documents pertinent to the enforcement of conditional sentence or community service. The director of the Administration for the Execution of Criminal Sanctions nominates the probation officer in accordance with the proposal of Head of the Department for Treatment and Alternative Sanctions. Moreover, it is particularly emphasized that the needs and personal characteristics of the convicted person must be taken into consideration during the selection of a Probation Service Officer.

When it comes to the number and structure of probation service staff, it should be mentioned that there are only 45 Probation Officers employed at Probation Service Office in Serbia. These are highly educated professionals

40 Criminal Code of the Republic of Serbia, Official Gazette of the Republic of Serbia, No. $85 / 2005,88 / 2005,107 / 2005,72 / 2009,111 / 2009$ and 121/2012.

41 Criminal Procedure Code, Official Gazette of SRJ, No. 70/2001 and 68/2002 an Official Gazette of the Republic of Serbia, No. 58/2004, 85/2005, 115/2005, 85/2005, 49/2007, 20/2009, $72 / 2009$ and 76/2010.

42 Law on the Execution of Criminal Sanctions, Official Gazette of the Republic of Serbia, No. $85 / 2005,72 / 2009$ and $31 / 2011$.

43 Law on Juvenile Perpetrators of Criminal Offences and Criminal-legal Protection of Minors, Official Gazette of the Republic of Serbia, no. 85/2005.

44 N. Mrvić-Petrović, Opus citatum, str. 55.

45 Regulation on the Enforcement of Conditional Sentence with Protective Supervision, Official Gazette of the Republic of Serbia, No. 20/2008.

46 Regulation on the Enforcement of Community Service, Official Gazette of the Republic of Serbia, No. 20/2008. 
(predominantly with the knowledge in the field of special pedagogy, psychology and social work) who have a lot of practical experience, which they gained throughout their professional engagement in penitentiary institutions. All Probation Officers also attended a one-day training organized by the Department for Treatment and Alternative Sanctions. The Officers and the Department for Treatment and Alternative Sanctions closely cooperate and regularly exchange relevant information, especially if any unresolved issues occur during the actual enforcement of alternative measures. Correction service offices have already been established in seven cities in Serbia and more of these offices are supposed to be opened in the future. Finally it is worth noting that some non-governmental organizations, such as NEOSTART, Centre for Crime Prevention and Post-penal Assistance from Belgrade for example, are also beginning to participate in the conduction of post-penal treatment in cooperation with the Administration for the Enforcement of Criminal Sanctions ${ }^{47}$. Projects, such as „The Right to Second Chance", have been initiated recently, and have not yet succeeded in becoming a part of common practice ${ }^{48}$. Regardless of being promising and optimistic the results of these pioneer efforts and their contribution to the reduction of recidivism and increase of public safety still need to be evaluated in the future.

The Strategy on the minimization of over-population of institutions for the execution of criminal sanctions in the Republic of Serbia for the period between 2010 and $2015^{49}$, recommended alternative sanctions as one of the most efficient means to achieve the decrease in the number of prisoners and reduce over-population of penitentiary institutions. The fact that their application was recommended by such an important strategic document was supposed to contribute to a broader implementation of alternative sanctions and to encourage relevant judiciary bodies to impose them whenever possible not only because they are beneficial for the offender and the community but also because they enable the reduction of prison population.

The most remarkable example of alternative sanctions and offender supervision - the so called house prison was introduced to Serbian legislation in 2009. In our penal system, house prison i.e. the execution of prison sentence in the premises where the sentenced person lives, with or without electronic surveillance is not an independent punishment but a special modality in which a prison sentence may be executed provided that all legal preconditions are fulfilled ${ }^{50}$. In spite of being introduced in 2009, it has to be highlighted that its enforcement did not begin until 2011, when all necessary legislative and practical preconditions and requirements for its execution were created ${ }^{51}$.

47 A. Batrićević; J. Srnić, J. Uloga udruženja građana u postpenalnom tretmanu, Revija $z a$ kriminologiju i krivično pravo, br. 2/2013, Beograd, str. 129-155.

48 NEOSTART Center for Crime Prevention and Post-penal Assistance, Project "Right of a Chance" [online], available at: http://neostart.webs.com/aktivnosti (16. 1. 2014).

49 Strategy for the Minimization of Over-population in the Institutions for the Execution of Criminal Sanctions in the Republic of Serbia in the period between 2010 and 2015, Official Gazette of the Republic of Serbia, No. 53/2010.

50 S. Konstantinović Vilić; M. Kostić, Sistem izvršenja krivičnih sankcija i penalni tretman $u$ Srbiji, Niš, 2011, str. 94.

51 D. Joka, The 2011 Annual Report on the Work of Administration for the Execution of Criminal Sanctions, Belgrade, 2012, str. 25. 
Another significant aspect of offender supervision that has also been neglected in our country is post penal treatment of former prisoners, which is supposed to be conducted in the first couple of months after their release from prison. The aim of post-penal treatment is to help offenders on their way to overcome various obstacles and difficulties after the release, to provide adequate advice, support and to facilitate their social reintegration in order to prevent recidivism. The preparation for release represents a part of pre-release treatment and post penal treatment, as its logical extension is an aspect of tertiary prevention and should be performed in cooperation with police, non-governmental organizations and other relevant associations. Although the Law on the Enforcement of Criminal Sanctions does oblige relevant state bodies to provide assistance to former prisoners on their way to rehabilitation and social reintegration, post penal treatment has not been conducted primarily due to an insufficient number of correction service offices and staff members and lack of financial resources ${ }^{52}$

Normative framework for the enforcement of modern alternative sanctions and offender supervision in Serbia was formed between 2006 and 2011. However, it appears that our country going to pass through another legislative reform in the area of execution of criminal sentences and post-penal treatment. The reason for that is the need to harmonize our legislation with the European standards and particularly to facilitate proper and effective implementation of Recommendation CM/ Rec (2010) 1 of the Committee of Ministers to member states on the Council of Europe Probation Rules, adopted on 20 January $2010^{53}$. In order to achieve these goals, our expert groups in the field of penal law created four draft documents: 1) Strategy of the development of the system of execution of criminal sentences in the Republic of Serbia in the period between 2013 and $2020^{54}$, 2) Law on the Execution of Criminal Sanctions $s^{55}$, 3) Law on the probation of execution of non-custodial sanctions and measures (i.e. Law on Probation) $)^{56}$ and 4) Strategy for social reintegration and acceptance of sentenced persons for the period between 2012 and $2015^{57}$ These documents have not yet become legally binding, but their official adoption by the Parliament will open the door for the implementation of offender supervision throughout the enforcement of various alternative or community sentences and measures, as well as during the period of the application of post-penal treatments and programs in accordance with European standards.

\section{$52 \quad$ Z. Nikolić, Opus citatum, str. 278-279.}

53 Recommendation CM/ Rec (2010)1 of the Committee of Ministers to member states on the Council of Europe Probation Rules, adopted by the Committee of Ministers on 20 January 2010, [online], available at: https://wcd.coe.int/ViewDoc.jsp?id=1575813. (16.1.2013).

54 Draft Strategy of the Development of the System of Execution of Criminal Sentences in the Republic of Serbia in the period between 2013 and 2020, [online], available at:http://www. mpravde.gov.rs/obavestenje/1561/radna-verzija-strategije-razvoja-sistema-izvrsenja-krivicnihsankcija-2013-2020.php (16.1.2013.)

55 Draft Law on the Execution of Criminal Sanctions, [online], available at: http://www.mpravde. gov.rs/obavestenje/1556/radna-verzija-zakona-o-izvrsenju-krivicnih-sankcija.php (16.1.2013).

56 Draft Law on the Probation of Execution of Non-custodial Sanctions and Measures [online], available at: http://www.mpravde.gov.rs/files/ZAKON\%20O\%20PROBACIJI\%2013\%205-13.doc (16. 1. 2013).

57 D. Joka, The 2011 Annual Report on the Work of Administration for the Execution of Criminal Sanctions, Belgrade, 2012, str. 85. 


\section{General Conclusions and Recommendations}

Due to their numerous psychological, social and economic advantages, noncustodial, alternative or community sanctions are nowadays widely recognized as powerful means of crime suppression and modern penal systems tend to be more and more focused on their development and adaptation to ever-changing needs and interests of offenders on one side and local community on the other. At the same time, avoiding the trial and ordering some pre-trial obligations, fulfillment of which may lead to conditional delaying of the procedure and offender's "liberation" in the so-called summary or abbreviated criminal procedure also appears to be a tendency rapidly spreading in modern criminal law. Finally, more intense post-penal treatment of former prisoners, particularly in the first couple of months after their release seems to be another significant method of crime prevention contemporary penal systems are investing in. Adequate and efficient application of the aforementioned institutions, in accordance with different and often opposite demands of offenders, victims and community or public safety would not be possible without a well-organized system of offender supervision conducted either through regular contacts with probation officers or with the help of electronic surveillance or via the combination of the two. There are several factors that impact the quality and the scope of implementation of offender supervision. Relevant theoretical sources and reports of several countries cited in this paper indicate that the most influential of these are: normative framework prescribing the preconditions for the imposing and enforcement of sanctions or probation measures containing supervision, the way that the execution of the latter is organized in practice, the number, geographical distribution, internal organization, financial capacities of probation offices, the number, educational level and professional knowledge, experience and motivation of probation officers, the cooperation between state bodies and non-governmental organization in the process of execution of these sanctions and measures, and, finally the way that probation and offender supervision are presented in the media and perceived by the community i.e. general public and experts as well as the way in which the offenders experience and perceive the entire process of supervision.

According to the presented data and the experience of European countries where offender supervision is applied in both - criminal procedure as well as in the process of the enforcement of imposed criminal sanctions, it appears that a gap between people's perceptions and the realities of supervision exists. For example, despite the fact that many changes within the organizational structures occurred, mainly justified on the grounds of enhancing the credibility of supervision in the eyes of the public, public support for the probation service has been declining in England and Wales, even though a significant support for the principle of rehabilitation exists, particularly when it comes to the reparative element. Moreover, the influence of media served to damage probation's reputation, especially when a series of criminal offences was committed by offenders serving community (non-custodial) sentences and being subject to some forms of supervision. However, the results of one of scientific studies on this issue suggest that the idea of "redeemability" exists in the public, and that 
people tend to believe that "everyone can change their ways and make good"58. This fact can be a powerful trigger to increase public confidence in the concept of alternative sanctions and the capacities of offender supervision in the field of crime prevention and suppression.

On the other hand, it appears that in comparison to England and Wales, people in Ireland have ambivalent attitudes towards community sanctions. A slight majority supported the use of community sanctions with offenders who had substance abuse problems and young offenders, whereas most of them have been becoming increasingly punitive in their attitudes in recent years. The consequence of this situation is the fact that the number of citizens who are actually advocating and defending the standpoint that alternative sanctions should be replaced with "traditional" punishments has been rising steadily. Nevertheless, crime has not yet become an important political issue in that country, despite the apparent rise in public's interest to punish the offenders, with the exception of the 1997 election when a short-lived moral panic, generated by several high-profile murders, took hold of the public imagination. However, community sanctions continue to play a significant, if minor role, in the Irish criminal justice system and the notion that prison should be used as a "stratagem of last resort" is frequently stressed. ${ }^{59}$

At the end, it should be mentioned that the Scottish system of probation might also be discussed as a potential role model for our country, with regard to its effectiveness and convenience for the implementation of the alternative sanctions. In Scotland, the probation officers obtained their formal training to varying degrees and learned the job principally from their peers - a regular finding in probation research. Probation practice was focused principally on diversion and containment, mainly with the young people, whereas the small number of adults on probation received casework or "treatment". This refers particularly to adult offenders with mental health problems. Also, one of the most important facts is that the Scottish probation officers were aware of the significance that the local community could have in the implementation of the alternative sanctions. Hence, they worked in a patch-based system with the purpose of building stronger informal sources of social support and control such as families, employers, former probationers, churches and youth organizations. As the consequence of this kind of relationship between probation officers and local community Scottish services were engaged with local communities, thus were always aligned to local council areas rather than to courts, despite occasional criticisms of this model ${ }^{60}$.

The analyses of data on alternative sanctions, probation and offender supervision in Serbia allows us to draw some conclusions that might be important for the depiction of current state and possibilities for future development and improvement of this area of criminal justice in our country. Available data

58 S. Maruna;A. King, Selling the Public on Probation: Beyond the Bib. Probation Journal, br. 4/2008, London, str. 344 .

59 S. Kilcommins; I. O’Donnell; E. O’Sullivan; B. Vaughan, Crime, Punishment and the Search for Order in Ireland, Dublin, 2004. str. 195.

60 F. McNeill, (2012). Experiencing Offender Supervision in Scotland. COST Action IS1106 Offender Supervision in Europe, Working group 1: Experiencing Supervision. [online], available at: http://www.offendersupervision.eu/wp-content/uploads/2012/10/Experiencing-Supervisionin-Scotland.pdf (17.1.2014). 
collected from the reports of the Administration for the Enforcement of Criminal Sanctions and regular Annual Reports of the Ombudsperson suggest that actual situation regarding the organization, capacities and functioning of the probation service is rather disturbing. There are several circumstances that lead to such conclusion, including financial, professional, organizational etc. However, the main reason for such assessment seems to be the lack of professional staff members who are involved in the probation service. Namely, the number of probation officers is insufficient, particularly in comparison to other countries, such as the Netherlands for example, and other professional engagements do not allow them to dedicate enough time to offenders under supervision. Besides, there seems to be a serious lack of cooperation with the non-governmental sector and organizations that are willing to support the offenders during their treatment (whether in-prison or post-penal), even though state authorities are aware of their existence and eagerness for cooperation. Moreover, although educational programs and professional trainings of the probation officers are conducted, their intensity frequency and orientation towards foreign experiences are not at the level that could be described as satisfactory. In addition it seems that the attitude of local community towards the alternative sanctions is not enough supportive. Instead, social stigmatization, exclusion, discrimination and fear of persons serving community sentences and former offenders still tend to be widely present in our society, which is confirmed by the reports of some nongovernmental organizations such as NEOSTART-Center for Crime Prevention and Post-penal Treatment as well as in the reports of the Ombudsperson.

To summarize, essential recommendations for further development in the field of alternative sanctions in Serbia could be to increase the number of probation officers, previously trained and educated at the appropriate level by national or foreign experts in this field, to support the cooperation with the nongovernmental sector and raise the awareness of the Ministry of Justice and Public Administration on the capacities of these organizations to assist state bodies in this process, to change the attitude of local community via media campaigns in which young people will be involved, to provide stronger financial support for scientific research in the area of alternative sanctions in Serbia by both - Ministry of Justice and Public Administration, and Ministry of Education, Science and Technical Development, and also to facilitate further exchange of experience and knowledge with foreign experts.

\section{References}

1. Batrićević A, Srnić J; Uloga udruženja građana u postpenalnom tretmanu, Revija za kriminologiju i krivično pravo., vol. 51, br. 2/2013, Institut za kriminološka I sociološka istraživanja, Srpsko udruženje za krivičnopravnu teoriju ipraksu, Beograd, 2013.

2. Bošković M, Radoman M; Penologija, Univerzitet. u Novom Sadu - Pravni fakultet, Novi Sad, 2002.

3. Criminal Code of the Republic of Serbia „Official Gazette of the Republic of Serbia”, No. 85/2005, 88/2005, 107/2005, 72/2009, 111/2009 and 121/2012. 
4. Criminal Procedure Code, „Official Gazette of SRJ“, No. 70/2001 and 68/2002 and „Official Gazette of the Republic of Serbia”, No. 58/2004, 85/2005, $115 / 2005,85 / 2005,49 / 2007,20 / 2009,72 / 2009$ and 76/2010.

5. Draft Law on the Execution of Criminal Sanctions, [online], available at: http:// www.mpravde.gov.rs/obavestenje/1556/radna-verzija-zakona-o-izvrsenjukrivicnih-sankcija.php, (16.01.2013.)

6. Draft Law on the Probation of Execution of Non-custodial Sanctions and Measures [online], available at: http://www.mpravde.gov.rs/files/ZAKON\%20 O\%20PROBACIJI\%2013\%205-13.doc (16.01.2013.)

7. Draft Strategy of the Development of the System of Execution of Criminal Sentences in the Republic of Serbia in the period between 2013 and 2020, [online], available at: http://www.mpravde.gov.rs/obavestenje/1561/radnaverzija-strategije-razvoja-sistema-izvrsenja-krivicnih-sankcija-2013-2020. php (16.01.2013.)

8. Durnescu, I. Pains of Probation: Effective Practice and Human Rights, International Journal of Offender Therapy and Comparative Criminology, vol. 55, br. 4/2010, SAGE Publications Ltd, London

9. Garside R, Mills H; UK Justice Policy Review. Volume 1. Centre for Crime and Justice Studies, The Hadley Trust, London, 2012.

10. Geiran, V, Mc Carthy M., Morahan M. and O'Connell V; Young Offenders in Penal Custody. Research and Statistics Unit, Probation and Welfare Service, Brunswick Press, Dublin, 1999.

11. Healy D, Experiencing Supervision in Ireland. COST Action IS1106 Offender Supervision in Europe, 2012 [online], available at: http://www. offendersupervision.eu/wp-content/uploads/2012/08/ExperiencingOffender-Supervision-in-Ireland.pdf 15.12.2013

12. Hoetjes V, Plaisier J; Experience of Probationers with the Dutch Probation Services: a quick scan. COST Action IS1106 Offender Supervision in Europe, 2012, str. 3. [on line], available at: http://www.offendersupervision.eu/wpcontent/uploads/2012/08/Offender-supervision-in-The-Netherlands.pdf (16.01.2014.)

13. Irish Court Service. (2012). Annual Report 2011, Stationery Office, Dublin, 2012, str. 21-52. [online], available at: http://www.courts.ie/Courts.ie/library3. nsf/(WebFiles)/87BE4631 14EF96FF80257BA20033953B/\$FILE/Courts\%20 Service\%20Annual\%20Report\%202012.pdf 15.12.2013.

14. Irish Prison Service, Annual Report 2011, Stationery Office, Dublin, 2012, str. 14., [online], available at: http://www.justice.ie/en/JELR/Annual\%20 Report\%20IPS\%202011.pdf/Files/Annual\%20Report\%20IPS\%202011.pdf 15.12.2013.

15. Joka D; The 2008 Annual Report on Prison Administration work, Ministry of Justice of the Republic of Serbia, Administration for Enforcement of Criminal Sanctions, Belgrade, 2009.

16. Joka D; The 2011 Annual Report on the Work of Administration for the Execution of Criminal Sanctions, Ministry of Justice of the Republic of Serbia, Administration for Enforcement of Criminal Sanctions, Belgrade, 2012. 
17. Kalmthout A M, Durnescu I (Eds.); Probation in Europe, Wolf Legal Publishers (WLP) Nijmegen, The Netherlands. 2009.

18. Kemshall H; Risk, rights and justice: Understanding and responding to youth risk, Youth Justice, vol. 8., br. 1/200, SAGE Publications Ltd, London.

19. Kilcommins S, O'Donnell I, O'Sullivan E and Vaughan B; Crime, Punishment and the Search for Order in Ireland. Institute of Public Administration, Dublin, 2004.

20. Konstantinović Vilić S, Kostić M; Penologija, Sven, Niš, 2006.

21. Konstantinović Vilić S, Kostić M; Sistem izvršenja krivičnih sankcija i penalni tretman u Srbiji, Sven, Niš, 2011.

22. L. Burke, W. Fitzgibbonn, Working Group on Experiencing Supervision Country Report: England and Wales. COST Action IS1106 Offender Supervision in Europe, 2013, str. 1. [online], available at: http://www.offendersupervision. eu/wp-content/uploads/2013/02/Experiencing-supervision-England-andWales-Country-Report-FINAL.pdf (15.12.2013.)

23. Law on Juvenile Perpetrators of Criminal Offences and Criminal-legal Protection of Minors, „Official Gazette of the Republic of Serbia”, No. 85/2005

24. Law on the Execution of Criminal Sanctions, „Official Gazette of the Republic of Serbia”, No. 85/2005, 72/2009 and 31/2011.

25. Maruna S, King A; Selling the Public on Probation: Beyond the Bib. Probation Journal, vol. 55, br. 4/2008, SAGE Publications Ltd, London.

26. McNeill F; A desistance paradigm for offender management, Criminology and Criminal Justice, vol. 6, br. 1/2006, SAGE Publications Ltd, London.

27. McNeill, F. (2012). Experiencing Offender Supervision in Scotland. COST Action IS1106 Offender Supervision in Europe, Working group 1: Experiencing Supervision. [online], available at: http://www.offendersupervision.eu/ wp-content/uploads/2012/10/Experiencing-Supervision-in-Scotland.pdf (17.01.2014.)

28. Ministry of Justice, Offender Management Caseload Statistics 2009: An Overview of the main findings. Ministry of Justice Statistics bulletin. United Kingdom Ministry of Justice, London, 2010.

29. Mrvić-Petrović N, Đorđević Đ; Moć i nemoć kazne, Vojnoizdavački zavod, Institut za kriminološka i sociološka istraživanja, Beograd, 1998.

30. Mrvić-Petrović N; Alternativne sankcije i novo zakonodavstvo Republike Srbije, Temida, vol. 9., br. 1/2006, Viktimološko društvo Srbije, Beograd.

31. National Crime Council, Fear of Crime in Ireland and its Impact on Quality of Life, Department of Justice, Equality and Law Refom, Dublin, 2009.

32. NEOSTART Center for Crime Prevention and Post-penal Assistance, Project "Right of a Chance", [online], available at: http://neostart.webs.com/aktivnosti (16.01.2014.)

33. Nikolić Z; Savremena penologija, Institut za kriminološka i sociološka istraživanja, Beograd, 2009.

34. O'Donnell I; Imprisonment and penal policy in Ireland, The Howard Journal of Criminal Justice, vol. 43., br. 3/2004, The Howard League and John Wiley \& Sons Ltd 
35. Petrus Consulting; Value for Money and Policy Review of the Community Service Scheme, Stationery Office, Dublin, 2009.

36. Recommendation CM/ Rec (2010) 1 of the Committee of Ministers to member states on the Council of Europe Probation Rules, adopted by the Committee of Ministers on 20 January 2010, [online], available at: https://wcd.coe.int/ ViewDoc.jsp?id=1575813. (16.01.2013.)

37. Regulation on the Enforcement of Community Service, „Official Gazette of the Republic of Serbia", No. 20/2008.

38. Regulation on the Enforcement of Conditional Sentence with Protective Supervision, „Official Gazette of the Republic of Serbia”, No. 20/2008.

39. Seymour M; Alternatives to Custody in Ireland Report, Irish Penal Reform Trust, Dublin, 2006.

40. Strategy for the Minimization of Over-population in the Institutions for the Execution of Criminal Sanctions in the Republic of Serbia in the period between 2010 and 2015, „Official Gazette of the Republic of Serbia”, No. $53 / 2010$.

41. Walmsley R; (2011). World Prison Population List (9th Ed). International Centre for Prison Studies, University of Essex, Essex, 2011.

42. Walsh, D. \& Sexton, P. (1999). An Empirical Study of Community Service Orders in Ireland. Dublin: The Stationery Office.

43. Weber J, Nett J; Country Report for Switzerland - A contribution to the working group no. 1 \& 2: Experiencing Supervision and Decision-Making. COST Action IS1106 Offender Supervision in Europe, 2013, str. 13. [online], available at: http://www.offendersupervision.eu/wp-content/uploads/2013/05/OffenderSupervision-in-Switzerland.pdf (16.01.2013.)

\title{
NADZOR PRESTUPNIKA U EVROPI - OPŠTI TRENDOVI I SRPSKO ISKUSTVO
}

\author{
Jelena Želeskov Đorić \\ Ana Batrićević \\ Institut za kriminološka i sociološka istraživanja, Beograd
}

Rezime: Alternativne sankcije ili sankcije koje se izvršavaju u zajednici (community sanctions) smatraju se u naučnoj literaturi, ali i u prakisi savremenih pravnih sistema kao izuzetno moćno sredstvo za prevenciju i suzbijanje kriminaliteta uopšte, a posebno recidivizma i to kako u slučaju maloletnih tako i u slučaju punoletnih prestupnika. Međutim, opšte je prihvaćen stav da izvršenje te vrste sankcija ili nije uopšte moguće ili nije u dovoljnoj meri efikasno i bezbedno bez primene adekvatnog mehanizma nadzora (supervizije) prestupnika 
kome su one određene. Nadzor prestupnika može se sprovoditi ili putem elektronskog monitoringa ili posredstvom razvijene mreže kancelarija za probaciju, koje omogućavaju ostvarivanje redovnih kontakata između prestupnika i poverenika za probaciju ili kombinovanjem ova dva modaliteta nadzora, u zavisnosti od okolnosti konkretnog slučaja. Zvanični izveštaji pojedinih evropskih zemalja, a posebno onih koje učestvuju na COST projektu (European Cooperation in Science and Technology) pod nazivom "Nadzor prestupika u Evropi” (Offender Supervision in Europe), poput Irske, Engleske, Velsa, Škotske, Śvajcarske i Holandije, pokazuju da primena nadzora prestupnikau sklopu alternativnih sankcija počinje da pruža zadovoljavajuće rezultate kada je u pitanju prevencija kriminaliteta i suzbijanje recidivizma, uprkos ambivalentnog stava zajednice prema ovoj formi sankcionisanja krivičnih dela. Iskustvo Srbije u izvršenju modernih alternativnih sankcija je prilično skromno i datira od 1. januara 2006. godine, kada je, nakon stupanja na snagu važećeg Krivičnog zakonika, $u$ naše pravo uveden rad $u$ javnom interesu kao posebna kazna. Zakonske izmene i dopune koje su učinjene 2009. godine dodatno su poboljšale uslove za primenu alternativnih sankcija, ali suštinske pozitivne promene bi trebalo da se dogode ako i kada sledeći nacti zakonskih odnosno podzakonskih akata steknu formalnu pravnu snagu: Nacrt zakona o izvršenju krivičnih sankcija, Nacrt zakona o probaciji izvršenja vanzavodskih sankcija i mera i Nacrt Strategije razvoja Sistema izvršenja krivičnih sankcija između 2013. i 2020. godine. Ovi dokumenti na više mesta naglašavaju izuzetan doprinos nadzora prestupnika uspešnosti i efikasnosti izvršenja probacije i ispunjavanja sledećih mera: obaveza u skladu sa odlukom javnog tužioca da odloži krivično gonjenje, obaveza iz sporazuma o priznanju krivice, zabrane napuštanja prostorija u kojima osuđeni stanuje sa ili bez elektronskog nadzora, zabrane prilaska, susreta ili komunikacije sa određenom osobom, rada $\mathrm{u}$ javnom interesu, uslovne osude, "kućnog zatvora", uslovnog otpusta i post-penalnog tretmana. Upoređujući podatke prikupljene iz Godišnjih izveštaja Uprave za izvršenje krivičnih sankcija sa onima koji su izloženi u zvaničnim izveštajima drugih Evropskih zemalja, a koji se odnose na sistem, organizaciju, implementaciju i kapacitete za nadzor prestupnika prilikom izvršenja alternativnih sankcija, autori izvode određene zaključke relevantne za poboljšanje postojećeg stanja u ovoj oblasti u Srbiji i njenog budućeg razvoja. U tom kontekstu, evropska zakonska rešenja i praktična iskustva analizirana su kao mogući uzori, koje bi trebalo slediti, uz uvažavanje postojećih ekonomskih i socijalnih prilika, našeg društva, ali i međunarodnih obaveza koje je naša zemlja preuzela ratifikacijom univerzalnih i regionalnih dokumenata relevantnih za tu oblast. Upoređivanje podataka iz izveštaja evropskih zemalja sa podacima navedenim u Izveštajima Uprave za izvršenje krivičnih sankcija pokazuje da treba ulagati više sredstava u edukaciju, zapošljavanje i organizaciju 
rada poverenika za probaciju, u saradnju sa civilnim sektorom kao i u naučna istraživanja i podizanje i menjanje društvene svesti o kapacitetima i prednostima vanzavodskih alternativnih sankcija i mera, a posebno onih koje uključuju superviziju prestupnika, u odnosu na "klasične“ krivične sankcije, kao što je, na primer kazna lišenja slobode. 